\title{
STUDY AND ANALYSIS OF POUNDING EFFECT BETWEEN ADJACENT RC BUILDINGS
}

\author{
A. D. Bhatt and G. P. Lamichhane* \\ School of Engineering, Pokhara University, Pokhara, Kaski, Nepal \\ E-mail: bhattanand39@gmail.com \\ * Faculty of Engineering, Mid-Western University, Birendranagar, Surkhet, Nepal
}

\section{ABSTRACT}

Pounding occurs when the adjacent buildings start vibration out of phase during the seismic activity which causes the collision between the adjacent structures. Due to higher cost of land in cities people have tendency to attach the buildings at property line. Earthquakes can cause pounding when adjacent buildings have little gap or no gap providing separation. Due to pounding effect structural and non - structural damage may occur in the adjacent buildings.

The main objective of this research is to assess the seismic response of common residential RC buildings that has been constructed with no gap with the adjacent structures and to find the minimum gap requirement for the commonly constructed buildings of Nepal.

For this study two different cases with varying separation distance between adjacent buildings have been considered. First case is the adjacent buildings having equal storey height but different number of stories. It includes models having 4 and 2 stories and 4 and 3 stories. Second case is the adjacent buildings having unequal storey height but same number of stories. It includes models having 3 and 3 stories and 4 and 4 stories. In both cases adjacent buildings have same material \& sectional properties. Non-linear dynamic analysis is performed using El-centro earthquake data as ground motion. Gap element has been used to simulate the pounding force between buildings. Adjacent buildings having different overall height are modelled in SAP $2000 \mathrm{v} 15$ using gap element for pounding study. The seismic responses in terms of joint displacement, joint acceleration, pounding force are presented. Joint displacement and joint acceleration comparison for both pounding and no pounding cases are presented.

Gap calculation from NBC and IS code, ABS and SRSS method was compared with gap required to avoid pounding force between adjacent structures and appropriate gap was recommended.

KEYWORDS: Pounding, Gap Element, Fast Non-linear Analysis (FNA), SAP 2000, Adjacent Buildings 


\section{INTRODUCTION}

Earthquake is a principal threat to build up Civil Infrastructure in seismically active areas. Our country, Nepal is seismically vulnerable region as it lies in subduction zone of Indo - Australian and Eurasian tectonic plate. Such region is prone to moderate to strong ground shaking. Buildings are major Civil Infrastructures that may get damaged due to earthquake. The rapid increase in population, higher land cost and unplanned urbanization has increases the buildings construction by adjoining the buildings at property line, which may causes pounding effect during earthquake. Therefore, there is a need of further researches and study to lessen the building damage due to pounding effect.

Pounding effect in building simply means collision between buildings due to earthquake load. Pounding is the result of irregular response of adjacent buildings of different heights and of different dynamic properties (Agrawal and Shrikhande, 2016). It is the phenomenon, in which two buildings strike due to their lateral movements induced by lateral forces (Noman et. al., 2016). Earthquakes can cause pounding when adjacent buildings have little or no gap providing separation. When two adjacent buildings collide, the resulting change in demand loads can lead to catastrophic collapse of one or both buildings.

Pounding may lead to two types of damages:

- Local damage at the point of contact

- Global damage resulting from the energy and momentum transfer in buildings due to collision

Local damage caused by the collision force while global damage depends upon dynamic properties of both buildings at the time of collision.

Earthquake causes sudden ground motion and ground shaking which is transferred from the ground to the superstructure through foundation (Chopra, 1996). In urban areas due to dense populated areas, residential and office buildings are often constructed very close to other with very less or no gap in between. Due to earthquake induced ground motion, these building starts vibrating out of phase and may collide with each other and causing damage to structure.

\section{Causes of Pounding}

Pounding damage is caused by hitting of two buildings constructed in close proximity with each other (Agrawal and Shrikhande, 2016). Structural Pounding damage can arise due the following:

- When separation gap between adjacent buildings is insufficient or zero (Agrawal and Shrikhande, 2016),

- When buildings have sufficient gap but they are connected by one or more members such as bridges (Noman et. al., 2016),

- When adjacent buildings have different dynamic properties like mass, height, orientation, geometry (Noman et. al., 2016). It is almost impossible to construct two buildings with same dynamic 
properties. If the dynamic properties of two buildings are same, then there will be no pounding even if the gap is zero.

Therefore, even if two buildings are constructed up to same height and connected at same roof level; there may occur damage due to pounding because dynamic properties like mass, height, stiffness etc. of both buildings may not be same which results in different time period of vibration of both buildings and ultimately pounding effect will occurs and leads to damage.

- If buildings have unsymmetrical or irregular lateral load resisting system in plan (Rajaram, 2011). This lead to rotation of building during earthquake motion, and due to rotation of building pounding effect may occur at adjacent building around periphery.

- Pounding may also occur because of noncompliance of codal provisions particularly for lateral and torsional stiffness (Agrawal and Shrikhande, 2016).

\section{Problem Statement}

In our country people have two options at property lines during building construction;

1. If they have sufficient land and want to use window then they leave minimum space for window (Nepal Building Code).

2. If they have adjustable land to construct house, then at property line they do not leave any gap between buildings.

Option second is mostly adopted in our country as there is no restriction of separation distance between adjacent buildings by metropolitan cities/municipalities even though NBC has provision of separation distance.

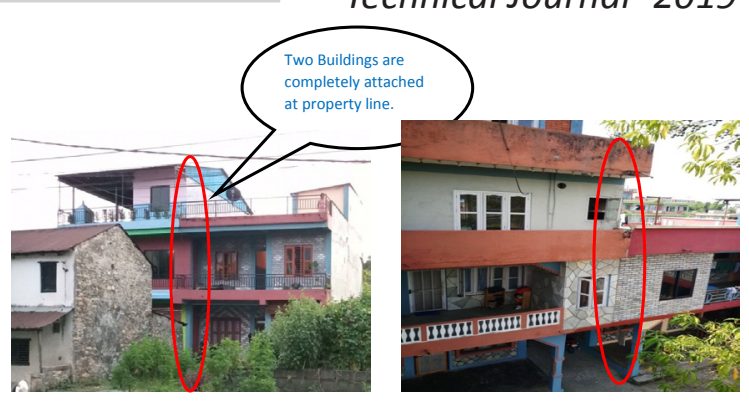

Figure 1 Common Construction Practice in Pokhara Metropolitan City/Problem in Construction Practice

\section{Research Objective}

Structural pounding is the complex phenomenon and is difficult to model physically and very complicated to represent analytically, there are very less researches related to Structural Pounding. Thus main objective of this research is to determine the effect of separation gap on pounding effect between general adjacent $\mathrm{RC}$ buildings and to recommend minimum separation distance between them.

Another objective of this study is to compare the response of general adjacent RC buildings in pounding case and no pounding case during earthquake.

\section{METHODOLOGY}

In order to fulfill the objective of this study, the following methods have been adopted.

- Two buildings having same plan, same and different storey height, same material property and same section property was taken for analysis.

- As both buildings have same material and sectional properties, buildings having same storey height and same overall height 
were not considered for analysis, as there is no pounding effect because of in-phase vibration of buildings.

- Buildings were modeled using software SAP 2000 v 15 and analysis was done using Non-linear Time History Analysis by taking time history data of El Centro earthquake.

- Study of pounding effect at connections of two building with gap element as nonlinear 2 link support.

\section{Parametric Study:}

Two cases were considered here.

Case 1: Two buildings having different number of stories but equal storey height. For this adjacent building having 4 and 2 stories, 4 and 3 stories were analyzed.

Case 2: Two building having same number of stories but unequal storey height. For this adjacent building having 3 and 3 stories, 4 and 4 stories were analyzed.

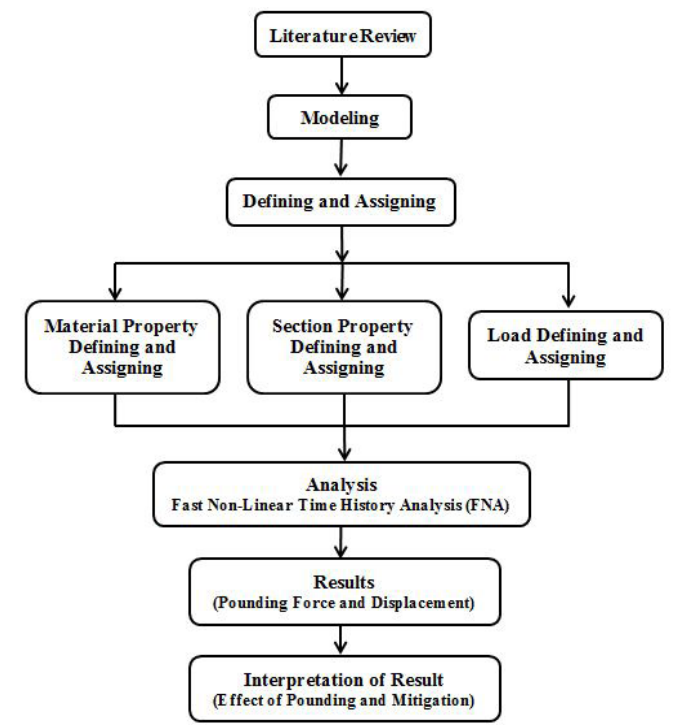

Figure 2 Methodology Flowchart for Pounding Effect Study

\section{BUILDING MODELING}

Table 1 Building Modeling Detailing

\begin{tabular}{ll}
\hline Building Detail & \\
\hline Plan Area & $7.62 \mathrm{~m} \times 10.98 \mathrm{~m}$ \\
Storey Height & $\begin{array}{l}10 \mathrm{ft} / 10 \mathrm{ft}(=3.049 \mathrm{~m}) \\
\text { for buildings having } \\
\text { same storey height } 10 \\
\mathrm{ft} \text { and } 9 \mathrm{ft} \text { for buildings } \\
\text { having different storey } \\
\text { height }\end{array}$ \\
& $300 \mathrm{~mm} \times 400 \mathrm{~mm}$ \\
Beam Size & $400 \mathrm{~mm} \times 400 \mathrm{~mm}$ \\
Column Size & $125 \mathrm{~mm}$ \\
Slab Thickness & Fe 415 \\
Steel Grade & $\mathrm{M} 20$ \\
Concrete Grade & \\
Loading & $3 \mathrm{kN} / \mathrm{m}^{2}$ for all floor \\
Live Load & except top $1.5 \mathrm{kN} / \mathrm{M}^{2}$ on \\
& terrace
\end{tabular}

Floor Finishing $1 \mathrm{kN} / \mathrm{m}^{2}$

Load

Wall Load

$11 \mathrm{kN} / \mathrm{m}$ of outer wall on outer peripheral beams $6 \mathrm{kN} / \mathrm{m}$ of inner wall on inner beams

Earthquake load As per IS 1893: 2002

Seismic Parameters

Seismic Zone

$\mathrm{v}($ Zone factor $=0.36)$

Soil Type Medium Soil (Type II Soil)

$\mathrm{R}$ e $\mathrm{s}$ p o n s e 5.0

Reduction Factor

Importance Factor $\quad 1.0$

Finite Element SAP $2000 \mathrm{v} 15$

Software 
Analysis Method Non - Linear Time

History Analysis

(Fast Non - Linear Analysis (FNA))

Model 1: Adjacent buildings having 4 and 2 stories but same storey height.

Model 2: Adjacent buildings having 4 and 3 stories but same storey height.

Model 3: Adjacent buildings having 3 and 3 stories but different storey height.

Model 4: Adjacent buildings having 4 and 4 stories but different storey height.

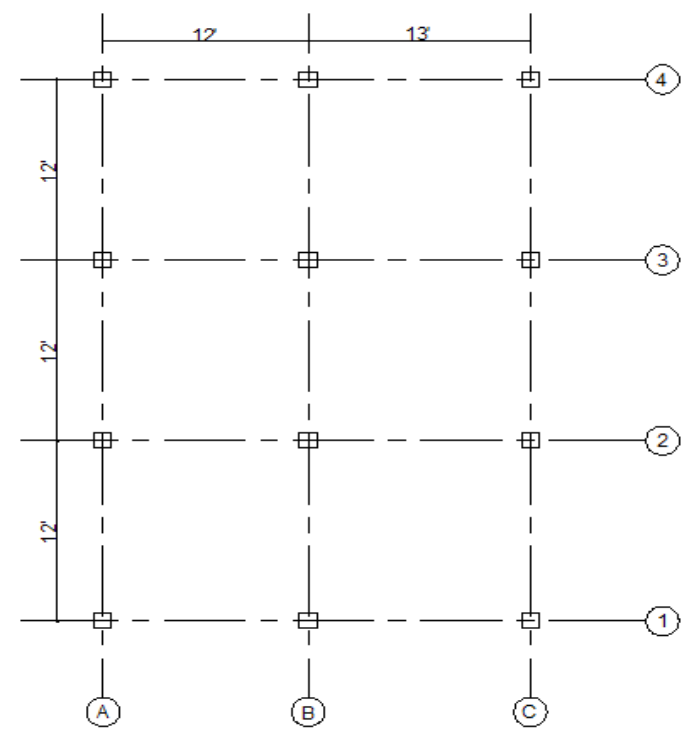

Figure 3 Common building plan adopted in Pokhara Metropolitan City taken for study
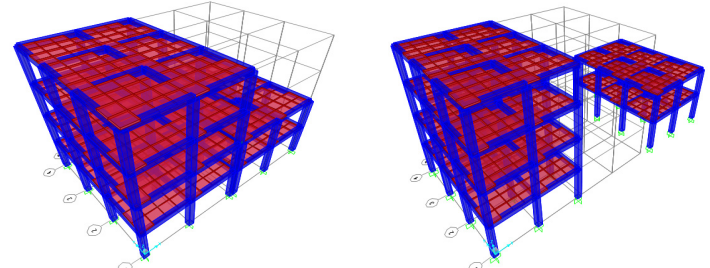

Figure 4 Building Model 1 a) Pounding Case, b) No Pounding Case
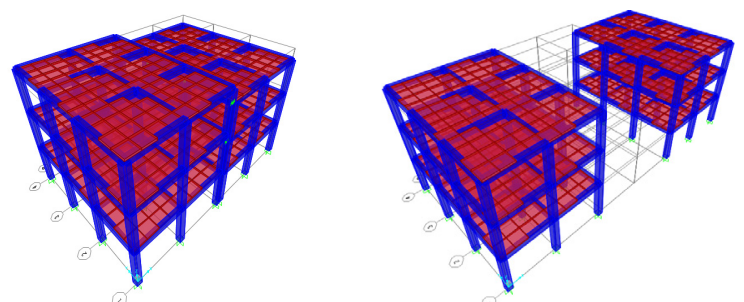

Figure 5 Building Model 2 a) Pounding Case, b)

No Pounding Case
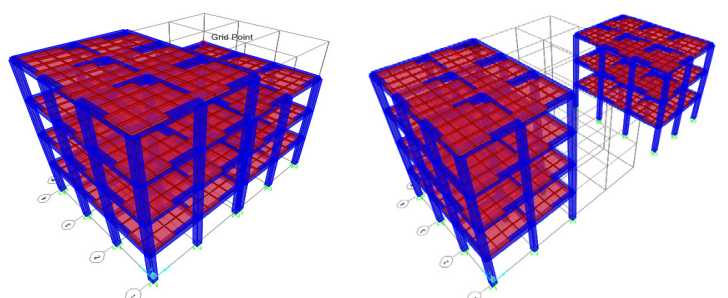

Figure 6 Building Model 3 a) Pounding Case, b) No Pounding Case
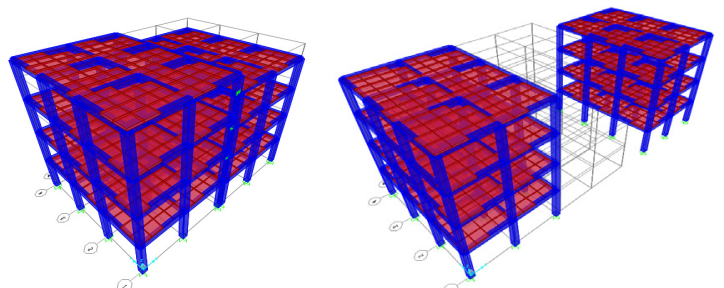

Figure 7 Building Model 4 a) Pounding Case, b) No Pounding Case

\section{ANALYSIS}

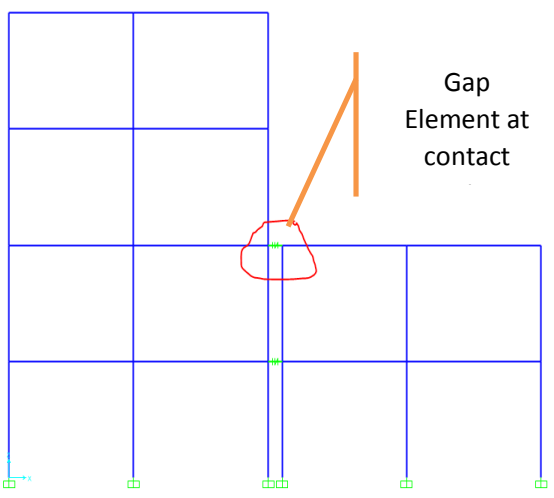

Figure 8 Gap elements modeling of Model 1 


\section{Seismic Data Input}

Traditionally for most of the common structures, seismic design is performed by the means of linear analysis either by equivalent lateral static loading or response spectrum analysis. But in some cases such as, irregular, highly ductile, critical or higher modes induced structures, linear analysis are not capable of estimating maximum response of structures, for which time - integration scheme is deemed more appropriate. A complete seismic design of structures requires non - linear time history analysis. In this research, time history data of El-Centro earthquake having peak ground acceleration $0.318 \mathrm{~g}$ at 2 second is taken.

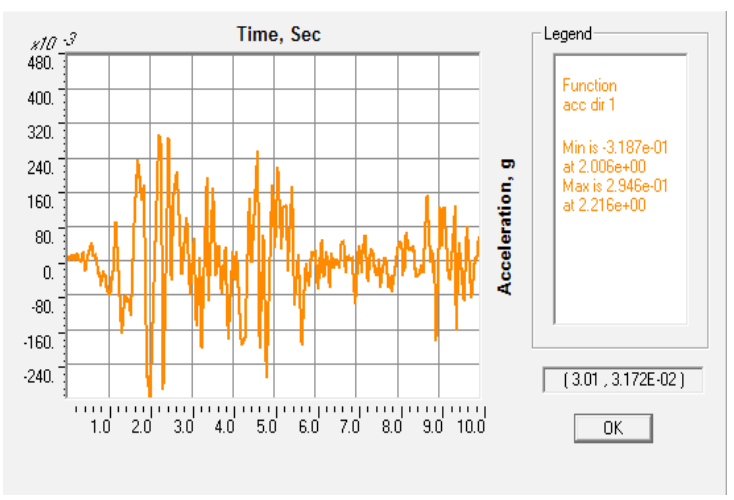

Figure 9 El - Centro Earthquake, 1940: Ground Motion Record of $0.318 \mathrm{~g}$ (PGA)

\section{RESULTS AND DISCUSSION}

\section{Fundamental Time Period}

Table 2 Fundamental time period of building models, in seconds

\begin{tabular}{|l|l|l|l|}
\hline \multicolumn{5}{|l|}{ For Model 1} \\
\hline Mode & For 4 - Storey Building $\left(\mathrm{T}_{1}\right)$ & For 2 - Storey Building $\left(\mathrm{T}_{2}\right)$ & Difference $\left(\mathrm{T}_{1}-\mathrm{T}_{2}\right)$ \\
\hline 1 & 0.886115 & 0.418465 & 0.46765 \\
\hline 2 & 0.853211 & 0.406785 & 0.446426 \\
\hline 3 & 0.736625 & 0.348032 & 0.388593 \\
\hline For Model 2 & \multicolumn{3}{l}{} \\
\hline Mode & For 4 - Storey Building $\left(\mathrm{T}_{1}\right)$ & For 2 - Storey Building $\left(\mathrm{T}_{2}\right)$ & Difference $\left(\mathrm{T}_{1}-\mathrm{T}_{2}\right)$ \\
\hline 1 & 0.886115 & 0.64817 & 0.237945 \\
\hline 2 & 0.853211 & 0.62659 & 0.226621 \\
\hline 3 & 0.736625 & 0.539659 & 0.140035 \\
\hline
\end{tabular}

\begin{tabular}{|l|l|l|l|}
\hline \multicolumn{3}{|l|}{ For Model 3 } \\
\hline Mode & $\begin{array}{l}\text { For Building having 10' storey } \\
\text { height }\left(\mathrm{T}_{1}\right)\end{array}$ & $\begin{array}{l}\text { For Building having 9' storey } \\
\text { height }\left(\mathrm{T}_{2}\right)\end{array}$ & Difference $\left(\mathrm{T}_{1}-\mathrm{T}_{2}\right)$ \\
\hline 1 & 0.648204 & 0.564444 & 0.08376 \\
\hline 2 & 0.626682 & 0.545254 & 0.081428 \\
\hline 3 & 0.539759 & 0.470341 & 0.069418 \\
\hline
\end{tabular}

For Model 4 


\begin{tabular}{|l|l|l|l|}
\hline Mode & $\begin{array}{l}\text { For Building having 10' storey } \\
\text { height }\left(\mathrm{T}_{1}\right)\end{array}$ & $\begin{array}{l}\text { For Building having } 9^{\prime} \\
\text { storey height }\left(\mathrm{T}_{2}\right)\end{array}$ & Difference $\left(\mathrm{T}_{1}-\mathrm{T}_{2}\right)$ \\
\hline 1 & 0.886115 & 0.77277 & 0.113345 \\
\hline 2 & 0.853211 & 0.743505 & 0.109706 \\
\hline 3 & 0.736625 & 0.643143 & 0.093482 \\
\hline
\end{tabular}

\section{Maximum Pounding Force}

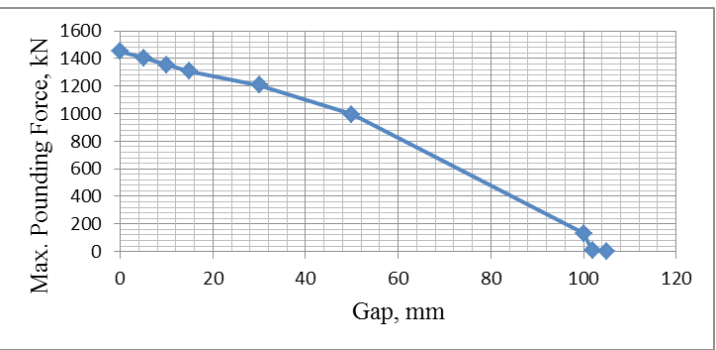

Figure 10 Maximum Pounding Force Vs Gap Graph for Model 1

In model 1, pounding force becomes zero when gap between adjacent buildings is equal to 105 $\mathrm{mm}$. Similarly, for model 2, model 3 and model 4, pounding force becomes zero when gap between adjacent buildings is equal to $145 \mathrm{~mm}$, $95 \mathrm{~mm}$, and $130 \mathrm{~mm}$ respectively.

\section{Joint Displacement}

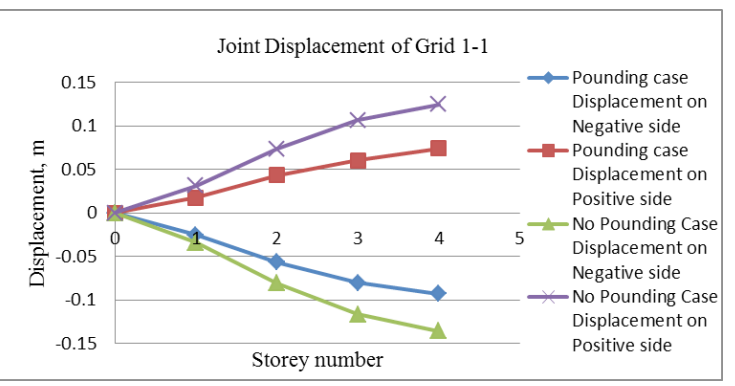

Figure 11 Four Storey Building of Model 1 (Grid 1-1)

Joint displacement of higher building in no pounding case is greater than that in pounding case but in adjacent lower height building just opposite result was found. This is due to facts that push force created by higher building in lower one.

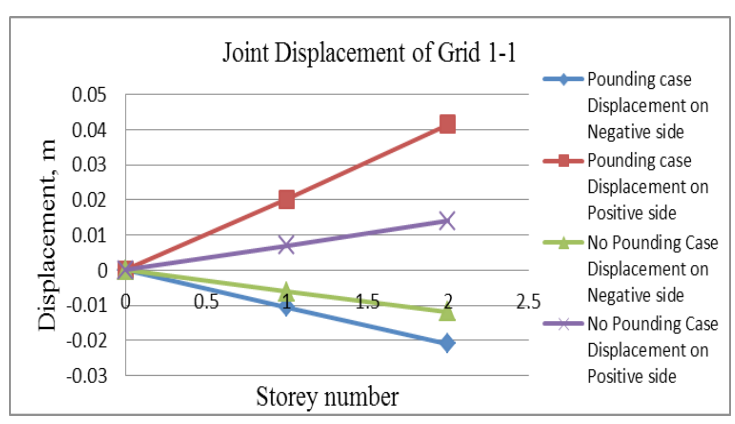

Figure 12 Two Storey Building of Model 1 (Grid 1 - 1)

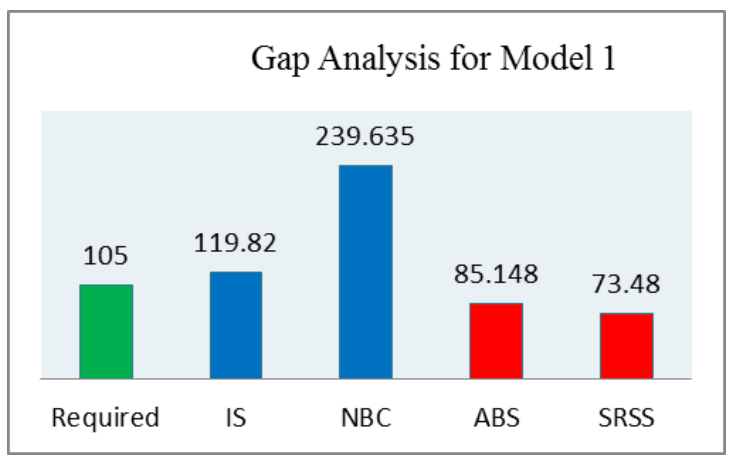

Figure 13 Gap Calculations for Model 1, in mm

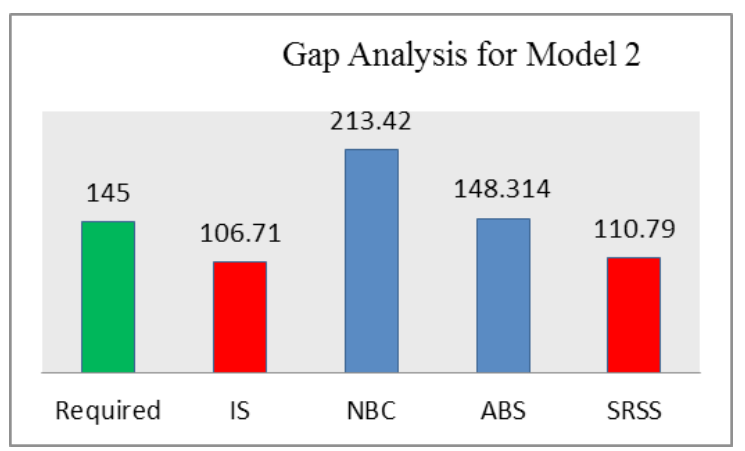

Figure 14 Gap Calculations for Model 2, in mm 
Nepal Engineers' Association, Gandaki

Gap Analysis

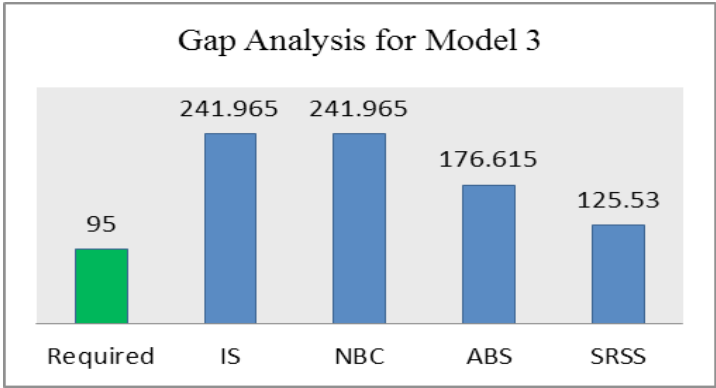

Figure 15 Gap Calculations for Model 3, in $\mathrm{mm}$

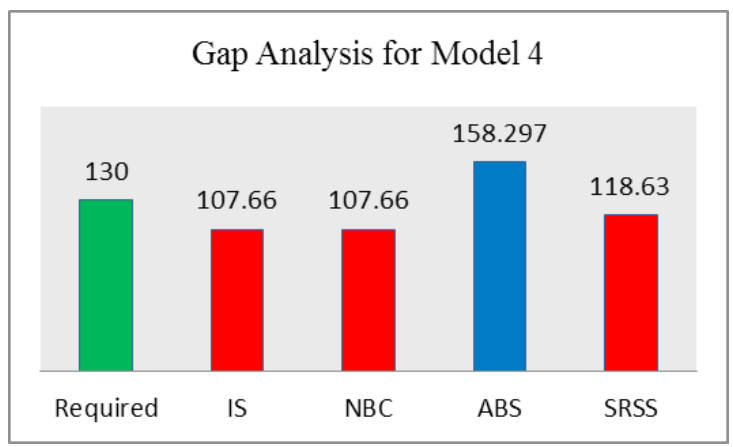

Figure 16 Gap Calculations for Model 4, in $\mathrm{mm}$

In model 1 and 2, NBC provides sufficient gap to avoid pounding effect between adjacent buildings. But in model 3 and 4, ABS method provides sufficient
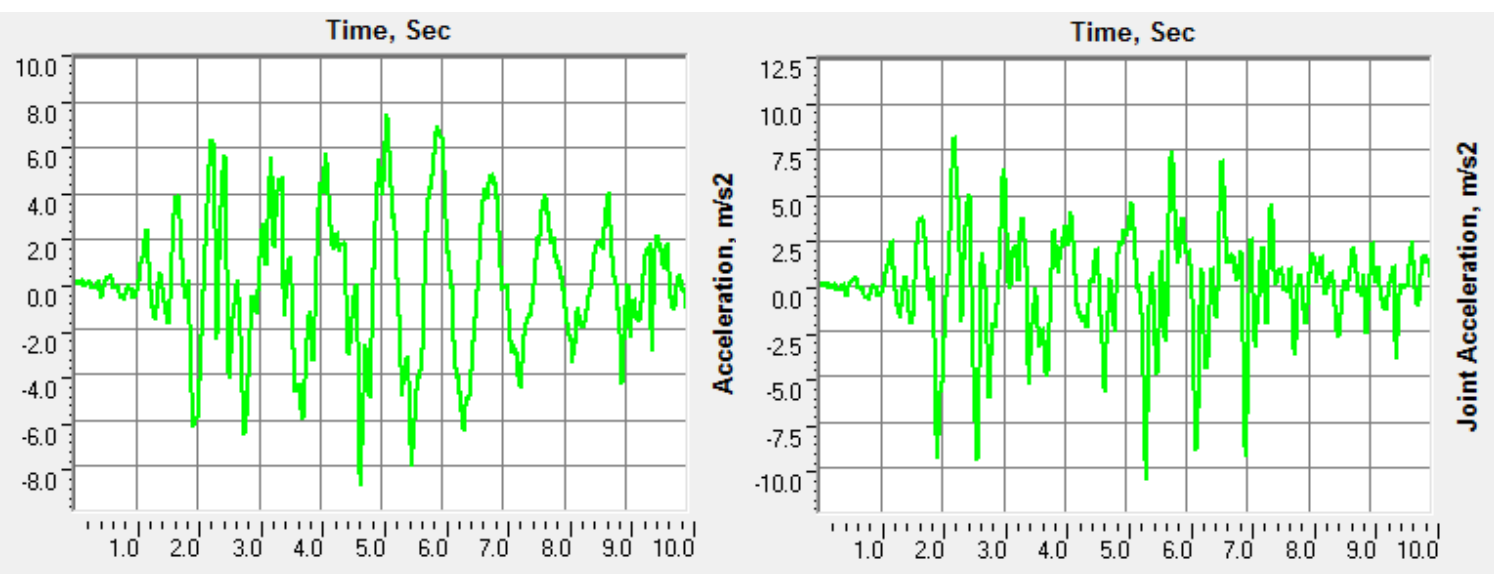

Figure 17 Joint Acceleration of top joint of 4 storey building of model 1, a) in no pounding case and $b$ ) in pounding case
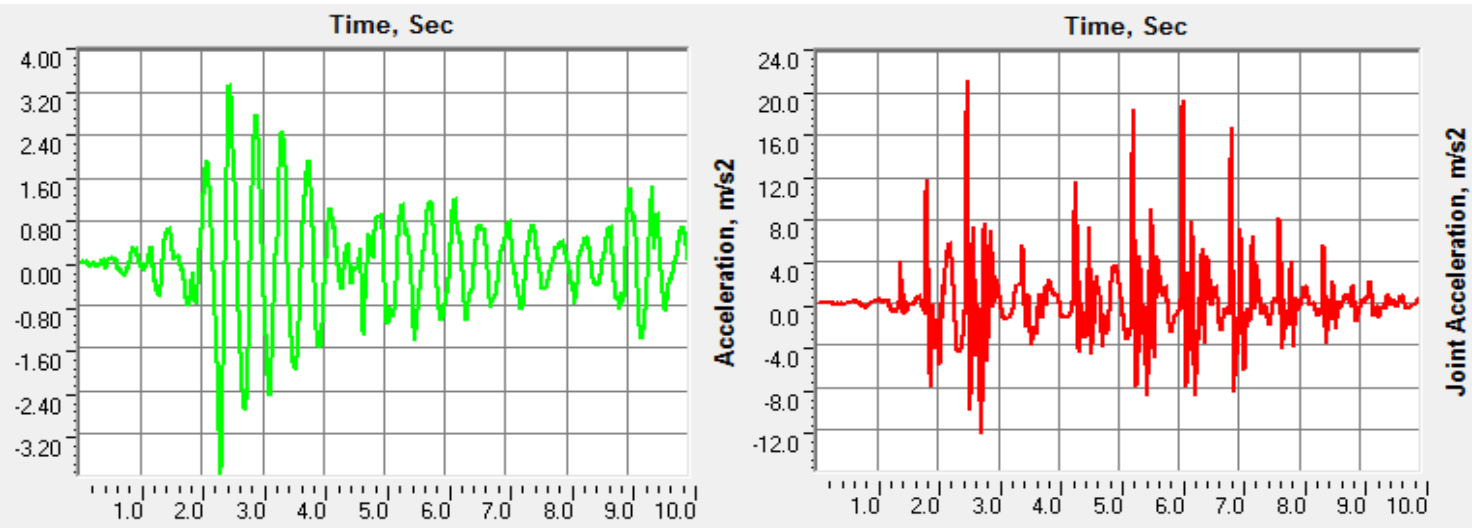

Figure 18 Joint Acceleration of top joint of 2 storey building of model 1, a) in no pounding case and $b$ ) in pounding case 
Joint acceleration and joint displacement of lower height building adjacent to higher building in pounding case is greater than that in no pounding case.

\section{CONCLUSION}

1. Joint acceleration and joint displacement of lower height building adjacent to higher building in pounding case is greater than that in no pounding case. Thus during ground motion, lower height building is more vulnerable to damage than adjacent higher building.

2. In case of pounding between adjacent buildings having storey level at same elevation but different number of stories, NBC provides sufficient gap and in this case NBC may be used to avoid pounding effect.

In case of pounding between adjacent buildings having storey level at different elevation but same number of stories, ABS method provides sufficient gap and in this case ABS may be used to avoid pounding effect.

3. For adjacent $\mathrm{RC}$ buildings up to 4 stories, pounding is experienced up to separation gap of $145 \mathrm{~mm}$ (5.71 inch) between buildings. Thus to avoid pounding between adjacent RC buildings up to 4 stories, 6 inch gap is sufficient.

For common residential RC building 6 inch gap is sufficient to avoid pounding between adjacent buildings. Thus in Pokhara Metropolitan City, for common residential $\mathrm{RC}$ buildings we can provide 6 inch gap between adjacent buildings from safety purpose to avoid damage due to pounding effect during ground motion.

\section{ACKNOWLEDGEMENT}

The authors thank to Dr. Tek Raj Gyawali, Dr. Hemchandra Chaulagain, Er. Dipendra Gautam, Dr. Sushil Khatiwada, Dr. Gokarna Bahadur Motra, Dr. Rajan Suwal, Dr. Hari Ram Parajuli for their kind assistance to perform this research.

\section{RERERENCES}

Agrawal P. and Shrikhande M., Earthquake Resistant Design of Structures, PHI Learning Pvt. Ltd., 2016.

Anagnostopoulos S. A., "Pounding of buildings in series during earthquakes", Earthquake

Engineering and Structural Dynamics, Vol. 16, 443-456, 1988.

Azevedo J. and Bento R., "Design Criteria for Buildings subjected to Pounding", Eleventh World

Conference on Earthquake Engineering, Lisbon, Portugal, ISBN 008042822 3, 1996.

Chopra A. K., Dynamics of Structures, Theory and Application to Earthquake Engineering, Prentice Hall, Englewood Cliffs, New Jersey, 1996.

Clough R. W., and Penzien J., Dynamics of Structures, Computers and Structures, Inc., Berkeley, CA 94704, USA.

CSI (2011), CSI Analysis Reference Manual for $S A P 2000 \AA, E T A B S \AA, S A F E \AA$ and CSiBridge ${ }^{\mathrm{TM}}$,

Computers and Structures, Berkley, California, USA.

FEMA, 356 (2000), PRESTANDARD AND COMMENTARY FOR THE SEISMIC REHABILITATION OF BUILDINGS, ASCE, Reston, Virginia.

Gautam D. and Rodrigues H., "Seismic 
vulnerability of vernacular Newari Buildings

in Nepal: observations and analysis of damage due to 1934, 1988, 2011, and 2015 earthquakes",

Natural Hazards and Earth System Sciences, 2018.

IITK-BMTPC - Earthquake tip 6, How Architectural Features affect Buildings during Earthquakes. Available: https:// www.nicee.org/EQTips.php. IS- 1893- Part I: 2002, Criteria for Earthquake Resistant Design of Structures, Bureau of Indian Standards, New Delhi.

IS- 1893- Part I: 2016, Criteria for Earthquake Resistant Design of Structures, Bureau of Indian Standards, New Delhi.

Jankowski R., "Non-linear viscoelastic modelling of earthquake induced structural pounding",

Earthquake Engineering and Structural Dynamics, Vol. 34, Pp: 595-611, 2005.

Kasai K., Jeng V., Patel P. C., Munshi J. A., "Seismic pounding effect - Survey and analysis",

Earthquake Engineering, Tenth World Conference, 1992, ISBN 9054100605.

Maison B. F., \& Kasai K., "Dynamics of pounding when two buildings collide", Earthquake

Engineering and Structural Dynamics, 21, 771786, 1992.

Mooty M. A., Al-Atrpy H. \& Ghouneim M., "Modeling and Analysis of factors affecting seismic

pounding of adjacent multi-story buildings", Earthquake Resistant Engineering Structures VII, WIT Transactions on The Built Environment, Vol 104, ISSN 1443-3509, 2009.

Nepal National Building Code NBC 105:1994, Seismic Design of Buildings in Nepal, Department of Urban Development and Building Construction, Kathmandu, Nepal.

Nepal National Building Code NBC 206:2015, Architecturel Design Requirements, Department of

Urban Development and Building Construction, Kathmandu, Nepal.

Noman M., Alam B., Fahad M., Shahzada K. and Kamal M., "Effect of Pounding on adjacent buildings of varying heights during earthquake in Pakistan", Cogent Engineering, 3:1225878, 2016.

Rajaram C., "A STUDY OF POUNDING BETWEEN ADJACENT STRUCTURES", MS by Research

Thesis, Earthquake Engineering Research Centre, International Institute of Information Technology, Hyderabad - 500 032, India, 2011. Shah P., "Seismic Pounding Effect on Row Housing", MSc Thesis, Department of Civil Engineering,

Pulchowk Campus, Tribhuvan University, Lalitpur, Nepal, 2011.

UBC 1997, Uniform Building Code Volume 2, International Conference of Building Officials,

South Workman Mill Road, Whittier, California, USA.

Wada A., Shinozaki Y., \& Nakamura N., "Collapse of building with expansion joints through

collision caused by earthquake motion", 8th World Conference on Earthquake Engineering,

4, pp. 855-862, San Francisco, CA, 1984.

Wilson E. L., Three - Dimensional Static and Dynamic Analysis of Structures, 3rd edition, Computers and Structures Inc., Berkeley, California, USA, 2002. 